LBNL-61454

\title{
Special Issue On Estimation Of Baselines And Leakage In Carbon Mitigation Forestry Projects
}

\author{
Jayant A. Sathaye*, Kenneth Andrasko\# \\ ${ }^{*}$ Lawrence Berkeley National Laboratory, Berkeley, CA 94720 \\ Tel.: +1-510-486-6294; Fax: +1-510-486-6996; JASathaye@lbl.gov \\ ${ }^{\#}$ U.S. Environmental Protection Agency, Office of Atmospheric Programs/CCD, Washington DC ${ }^{\#}$ Tel.: +1-202-343-9281, Fax: +1- \\ 202-343-2202.andrasko.ken@epa.gov
}

There is a growing acceptance that the environmental benefits of forests extend beyond traditional ecological benefits and include the mitigation of climate change. Interest in forestry mitigation activities has led to the inclusion of forestry practices at the project level in international agreements. Climate change activities place new demands on participating institutions to set baselines, establish additionality, determine leakage, ensure permanence, and monitor and verify a project's greenhouse gas benefits. These issues are common to both forestry and other types of mitigation projects. They demand empirical evidence to establish conditions under which such projects can provide sustained long term global benefits. This Special Issue reports on papers that experiment with a range of approaches based on empirical evidence for the setting of baselines and estimation of leakage in projects in developing Asia and Latin America.

Over the last decade, authors have developed alternative approaches for setting baselines that are either project-specific or regional. The latter apply to many project activities within a GHG assessment boundary. Both approaches have been applied to lands that display a range of biophysical and socioeconomic properties. The project-specific approach has been criticized as being subjective, lacking in transparency, offering the potential to generate inconsistent baselines for similar projects, and one that incurs high transaction costs. The use of regional baselines can address most of these issues but requires careful stratification into relatively homogeneous land polygons in order to ensure that baselines adequately represent the underlying differences within the assessment boundary. 
A second issue that has been noted as a cause for concern is the leakage associated with mitigation projects. Leakage refers to the possibility that net emissions reductions of a project may be lower (or higher) because of increased (decreased) emissions elsewhere that are attributable to the project. This is a particular concern in cases where land users are displaced and turn to other areas outside the project boundary to earn their livelihood from cultivation of forested land. The magnitude of leakage can be large enough to negate the carbon benefits of a project, and hence warrant empirical studies to estimate leakage.

The existing literature relevant for leakage assessment establishes definitions and typologies and a framework for analysis. Empirical estimates of leakage have been reported at the multi-region and multisector or global levels. There is little or no information, however, of empirical estimates of leakage at the project-level. The papers in this issue fill this critical gap. They report significant potential leakage for deforestation avoidance projects, but also ways that leakage can be avoided as illustrated by positive leakage in the case of the Mexico Scolel Té project. Leakage is much lower or negligible for afforestation projects, where the project land has low opportunity cost (for example, wastelands in India), although it can be significant for lands producing commodities traded on regional markets. 
This Special Issue reports on empirical studies in developing countries (Latin America and Asia) that examine alternative approaches for setting baselines and estimating leakage for projects that avoid deforestation and promote carbon sequestration. Sathaye and Andrasko, in their summary paper, report on the pros and cons of setting baselines using the earlier project-specific and regional approaches. For each approach, they report on the key characteristics such as consistency of baselines for similar projects, use of stratified baselines, temporal period for input data, and future validity period. Based on a review of the literature on the application of the two approaches across the developing and industrialized countries, they provide a summary classification of regional baseline approaches by type of land use. They conclude by identifying potential steps for the setting of stratified regional baselines for estimating emissions reductions or sequestration from forestry and land-use change projects. The steps are illustrated with an application to an afforestation example for the Mississippi Valley in the United States.

Brown, et al. report on the use of three different models to derive regional baselines at six sites in Latin America Tropics; one each in Belize, Bolivia, and Brazil and three in Mexico. The first model is Food and Agricultural Organization's (FAO) Forest Area Change (FAC) model that includes historical data on forest cover and population density as the driver variables. It is applied to large regions and has the advantage of requiring minimal data, and low costs. Its disadvantages include lack of spatial resolution, and reliance on only two variables. The second approach uses the Land-use Carbon Sequestration (LUCS) model that relies on data on current land use patterns, agricultural land required, and traded agricultural products as drivers, and relates per capita demand to population growth. Its advantages include the ability to model many types of land use changes at different scales but it too lacks spatial resolution, and requires assumptions about poorly- known parameters. The third approach uses Geographical Modeling (GEOMOD) that includes spatially distributed data to simulate landscape dynamics. It sorts many driver variables to select the ones with the highest correlation to deforestation. The model permits spatial resolution at any scale, and allows evaluation of model performance versus chance. It requires, however, large amounts of data, a high model validation effort, and higher cost for data acquisition and analysis. They report that for 
one example project, Noel Kempff in Bolivia, the FAC approach projects baseline carbon emissions over 20 years of $11.54 \mathrm{Tg}$ C, the LUCS approach results in $0.18 \mathrm{Tg} \mathrm{C}$ and the GEOMOD approach in $1.05 \mathrm{Tg}$ of $\mathrm{C}$ emissions. The GEOMOD approach thus yields an estimate that is an order of magnitude larger than the LUCS approach, but an order of magnitude lower than the FAC estimate. The GEOMOD approach tracks the changes in carbon stock annually, and shows substantial year to year variation in t C/ha, which the other two approaches are not able to represent. Thus, the baseline setting methodology and the selected GHG assessment region have a major influence on the magnitude of the baseline estimate.

Boer et al. report on the setting of baselines and the estimation of leakage for the Batanghari district in Jambi, Indonesia. They develop a regional baseline for a hypothetical set of projects using a model similar to GEOMOD above that uses site-specific data and remote sensing of historical land-use trends. The model sorts many driver variables to select ones that have the highest correlation to deforestation. It allows for estimation of leakage for multiple projects within the administrative district, which serves as the baseline accounting region. Its disadvantages are the same as those for GEOMOD. The study estimates that leakage exceeds the carbon that would be sequestered within the project area and hence would result in a net loss of carbon unless measures to manage leakage are implemented.

Lasco, Pulhin and Sales analyze leakage in a hypothetical multi-component project in the Magat watershed in the Philippines using a different approach than that used by Boer et al. The three main components of the project are forest conservation, tree plantations, and agroforestry farm development. At year 30, the watershed can attain a net carbon benefit of $19.5 \mathrm{M} \mathrm{t} \mathrm{C}$. The potential leakage of the project is estimated using historical experience in technology adoption in watershed areas in the Philippines. Most of the leakage occurs in the first 10 years of the project as displacement of livelihood occurs during this time. The carbon lost via leakage ranges from 3.7 Mt C (19\%) in the historical adoption scenario to $8.1 \mathrm{Mt}$ C (41\%) under the enhanced adoption scenario. Leakage thus reduces but does not offset the estimated net carbon benefit. 
De Jong, Bazán and Montalvo analyzed leakage for the multi-component Scolel Té project in Mexico, in which communities participating in the project are scattered over a large heterogeneous landscape. The project has been in operation for almost a decade. The leakage assessment is based on the Climafor analytic project's regional baseline. No negative leakage was detected in the Scolel Té project. Some slight positive sources of leakage were observed in the rate of deforestation and related carbon emissions, both for the individual farmers and the two communities. The Scolel Té project is thus an example in which leakage in forestry projects can be dealt with effectively if efforts are undertaken to identify the possible sources of leakage and their main drivers and measures such as permanent sustainable agriculture are pursued to avoid activity-shifting leakage.

Table 1 summarizes leakage estimates in the studies presented here, compared to the literature. It finds that afforestation in the tropics on marginal lands with low opportunity costs, and minimal production of commodities traded on regional markets, has less than $10 \%$ leakage on community lands assessed in two actual projects being implemented (Scolel Té in Mexico, and several projects in the Kolar district, India) and two hypothetical analyses in India. Another hypothetical case in India estimates 20\% leakage on farm forestry lands producing poles as a commodity, and a hypothetical project on degraded and forest lands in the Philippines estimates leakage of $19-41 \%$.

These estimates are significantly lower than afforestation estimates globally (about 50\%) or in the US (18-42\%), where timber is assumed to be produced and sold in national and global markets. Avoided deforestation has a much wider range of leakage in analyses to date (0-92\%), and appears to increase as the region of analysis is expanded, e.g., the Wear and Murray (2004) estimates in Table 1 clearly increase as the scale is expanded.

\section{PLACE TABLE 1 HERE}

Five papers present a set of consistent, nested analyses in India from the project to the national scale, developed under the FORCLIMIT-India project of U.S. Environmental Protection Agency, Lawrence Berkeley National Laboratory, Indian Institute of Science, and Indian Council for Forestry Research and Education (ICFRE). Ravindranath, Murthy, Sudha et al. in their Kolar district project analysis that 
includes the existing Bagepalli agroforestry project evaluate community and farm forestry baselines for afforestation, and mitigation potential, on 14,00 ha. They find afforestation rate data from 1995 or 1998 to the present and make projections out to 2035 using the PROCOMAP model, estimate uncertainties, cost effectiveness of short rotation timber and long rotation options (4-10\% internal rate of return (IRR)) and of mango fruit orchards (most profitable at 30\% IRR), investment requirements by option, and leakage estimates (less than 1\%).

Hooda et al. evaluate a farm forestry (private croplands) and a community degraded common uplands hypothetical project case using the PROCOMAP model in a parallel analysis to that of Ravindranath et al. They find that community forestry options on upland sites have mostly negative to very low IRRs in the base case, but rise to 13-39\% IRRs if carbon benefits are included, demonstrating that carbon revenues can make a major difference for low-value land management systems. The story for private croplands is different, however, as baseline case financial returns are 9-37\% without carbon revenues, and thus have higher opportunity costs and carbon price hurdle rates.

Sudha, Ramprasad et al. assess farm forestry baseline and mitigation potential surrounding a large private paper mill in Dhammam district, Andhra Pradesh, eastern India, and conclude that a regional baseline approach would be difficult to implement, since the carbon density in soils varies significantly across the district.

A regional baseline setting exercise was undertaken for the Kolar district in Karnataka, India by Sudha, Shubhashree, et al. in a separate paper. Kolar has 2 million ha of wastelands comprising about $11 \%$ of the state, of which 297,000 ha were include in the regional baseline evaluation. They found that a regional approach for degraded land afforestation was feasible, and highly cost effective (about a quarter of the cost of a project-specific approach), although this case was relatively simple, with minimal land use change, compared to many tropical settings.

These studies together reveal the importance of soil organic carbon estimation methods in the baseline case and monitoring plans in the project case, since minimal above-ground vegetation exists on 
degraded wastelands targeted for some options, and C benefits from mitigation are substantial belowground and hence small on a per ha basis.

In summary, the papers in this issue illustrate that baseline estimates vary substantially by: a) the extent to which a model is able to represent the stratification of the region's biophysical and socioeconomic parameters, b) the geographic scale of the GHG assessment region selected for a project; and c) the model or methods used for analysis. A step-wise approach for setting baselines that considers appropriate stratification of the GHG assessment region and the length of the historical time period to use for selection of input data can improve the applicability of a regional baseline to a specific project located within the region.

The papers also confirm that leakage can be an important issue for avoided deforestation projects, but measures to overcome it have been successfully demonstrated. By the same token, leakage was not found to be significant for afforestation projects on lands with low opportunity costs that do not produce commodities traded on regional markets. Thus, projects will need to be carefully sited to minimize leakage, designed to mitigate local or national leakage if expected, and/or use regional look-up tables developed in time from national and global timber trade models, if they seek to take international leakage into account. However, taking leakage into account, or not, and how, are significant policy issues that GHG mitigation programs worldwide likely will face. IPCC Good Practices Guidelines for reporting emissions and uptake from other sectors besides LULUCF do not require leakage estimation or discounting of mitigation benefits. To require them for forestry projects provides a disincentive and non-level playing field for this sector, as noted in a recent workshop summary on avoided deforestation as an emerging mitigation option (Bad Blumau workshop summary, 2006)

\section{Acknowledgement}

This work was supported by the U.S. Environmental Protection Agency, Office of Atmospheric Programs through the U.S. Department of Energy under Contract No. DE-AC02-05CH11231. Disclaimer: The views and opinions of the authors herein do not necessarily state or reflect those of the United States Government or the Environmental Protection Agency. 


\section{References}

Bad Blumau Workshop Summary (2006) Reducing emissions from deforestation in developing countries workshop, 10-12 May 2006, Bad Blumau, Austria. Fast-track draft summary for SB side event, 19 May 2006, Bonn, Germany, 4 pp., available at http://www.joanneum.at

Boer R, Wasrin U, et al (this issue) Assessment of carbon leakage in multiple carbon-sink projects: A case study in Jambi province, Indonesia

Brown S, Hall M, et al (this issue) Baselines for land-use change in the tropics: Application to avoided deforestation projects

De Jong BHJ, Bazán EE, et al (this issue) Application of the “Climafor” baseline to determine leakage: The case of Scolel Té

Hooda N, Gera M, et al (this issue) Community and farm forestry climate mitigation projects: Case studies from Uttaranchal, India

Lasco, RD, Pulhin, FB, et al (this issue) Analysis of leakage in carbon sequestration projects in forestry: The case of upper Magat watershed

Murray BC, McCarl BA, et al (2004) Estimating leakage from forest carbon sequestration programs. Land Economics 80(1):109-124

Ravindranath NH, Murthy IK, et al (this issue) Methodological issues in forestry mitigation projects: A case study of Kolar district

Sathaye JA, Andrasko, K. (this issue) Land use change and forestry climate project regional baselines: A review.

Sedjo R, Sohngen B (2000) Forestry sequestration of $\mathrm{CO}_{2}$ and markets for timber. Washington, DC, Resources for the Future, Discussion Paper 00-03, 51 p

Sohngen B, Brown S (2004) Measuring leakage from carbon projects in open economies: A stop timber harvesting project case study. Can. J., For. Res. 34:829-39

Sudha P, Shubhashree D, et al (this issue) Development of regional climate mitigation baseline for a dominant agro-ecological zone of Karnataka, India

Sudha P, Ramprasad V, et al (this issue) Methodological issues in forestry projects: A case study of Kolar district.

US EPA (2005) Greenhouse Gas Mitigation Potential in U.S. Forestry and Agriculture. Washington, DC, EPA 430-R-006, November, $150 \mathrm{p}$

Wear D, Murray BC (2004) Federal timber restrictions, interregional spillovers, and the impact on U.S. softwood markets. Jour. of Envir. Econ. and Management 47(2):307-330 
Table 1: Forestry mitigation activity leakage estimates by activity and region from this issue, compared to other literature

\begin{tabular}{|c|c|c|c|c|}
\hline Activity & Region & $\begin{array}{c}\text { Leakage } \\
\text { Estimation } \\
\text { Method } \\
\end{array}$ & $\begin{array}{c}\text { Estimated } \\
\text { Leakage Rate (\% } \\
\text { of C mitigation) }\end{array}$ & Source \\
\hline \multicolumn{5}{|c|}{ Afforestation: Tropical Region Estimates } \\
\hline $\begin{array}{l}\text { Afforestation of } \\
\text { degraded lands }\end{array}$ & $\begin{array}{l}\text { Kolar district, } \\
\text { Karnataka, India } \\
\text { hypothetical } \\
\text { project }\end{array}$ & $\begin{array}{c}\text { Household } \\
\text { wood demand } \\
\text { survey }\end{array}$ & 0.02 & $\begin{array}{l}\text { Ravindranath, } \\
\text { Murthy, } \\
\text { Sudha et al, } \\
\text { this issue }\end{array}$ \\
\hline $\begin{array}{l}\text { Plantations, forest } \\
\text { conservation, } \\
\text { agroforestry of } \\
\text { degraded lands }\end{array}$ & $\begin{array}{c}\text { Magat watershed, } \\
\text { Philippines } \\
\text { hypothetical } \\
\text { project }\end{array}$ & $\begin{array}{l}\text { Historical } \\
\text { rates of } \\
\text { technology } \\
\text { adoption }\end{array}$ & $19-41$ & $\begin{array}{l}\text { Authors } \\
\text { estimates } \\
\text { based on } \\
\text { Lasco et al., } \\
\text { this issue }\end{array}$ \\
\hline $\begin{array}{l}\text { Afforestation on } \\
\text { small landowner } \\
\text { parcels }\end{array}$ & $\begin{array}{l}\text { Scolel Té project, } \\
\text { Chiapas, Mexico }\end{array}$ & $\begin{array}{c}\text { Household } \\
\text { wood demand } \\
\text { survey }\end{array}$ & $\begin{array}{c}0 \\
\text { (some positive } \\
\text { leakage) }\end{array}$ & $\begin{array}{l}\text { De Jong et al., } \\
\text { this issue }\end{array}$ \\
\hline $\begin{array}{l}\text { Afforestation } \\
\text { degraded uplands }\end{array}$ & $\begin{array}{c}\text { Betalghat } \\
\text { hypothetical } \\
\text { project, } \\
\text { Uttaranchal, India }\end{array}$ & $\begin{array}{c}\text { Household } \\
\text { wood demand } \\
\text { survey }\end{array}$ & $\begin{array}{l}10 \\
\text { from fuelwood, } \\
\text { fodder }\end{array}$ & $\begin{array}{l}\text { Hooda et al., } \\
\text { this issue }\end{array}$ \\
\hline $\begin{array}{l}\text { Afforestation, farm } \\
\text { forestry }\end{array}$ & $\begin{array}{c}\text { Bazpur } \\
\text { hypothetical } \\
\text { project, } \\
\text { Uttaranchal, India }\end{array}$ & $\begin{array}{c}\text { Household } \\
\text { wood demand } \\
\text { survey }\end{array}$ & $\begin{array}{l}20 \\
\text { from fuelwood, } \\
\text { poles }\end{array}$ & $\begin{array}{l}\text { Hooda et al., } \\
\text { this issue }\end{array}$ \\
\hline \multicolumn{5}{|c|}{ Afforestation: Global and Temperate Region Estimates } \\
\hline $\begin{array}{l}\text { Afforestation } \\
\text { (plantation } \\
\text { establishment) }\end{array}$ & Global & PEM & $0.4-15.6$ & $\begin{array}{l}\text { Sedjo and } \\
\text { Sohngen, } \\
2000\end{array}$ \\
\hline Afforestation & USA wide & PEM & $18-42$ & $\begin{array}{l}\text { Murray et al., } \\
2004\end{array}$ \\
\hline Afforestation only & USA wide & PEM & 24 & US EPA, 2005 \\
\hline $\begin{array}{l}\text { Afforestation and } \\
\text { forest management } \\
\text { jointly }\end{array}$ & USA wide & PEM & $-2.8 *$ & US EPA, 2005 \\
\hline \multicolumn{5}{|c|}{ Avoided Deforestation: Tropical Region Estimates } \\
\hline $\begin{array}{l}\text { Avoided } \\
\text { deforestation }\end{array}$ & $\begin{array}{c}\text { Bolivia, Noel } \\
\text { Kempff project } \\
\text { and national } \\
\end{array}$ & PEM & $\begin{array}{l}\text { 5-42 undiscounted } \\
\text { 2-38 discounted }\end{array}$ & $\begin{array}{l}\text { Sohngen and } \\
\text { Brown, } 2004\end{array}$ \\
\hline \multicolumn{5}{|c|}{ Avoided Deforestation and Biofuels: Temperate Region Estimates } \\
\hline $\begin{array}{l}\text { Avoided } \\
\text { deforestation }\end{array}$ & Northeast USA & PEM & $41-43$ & US EPA, 2005 \\
\hline $\begin{array}{l}\text { Avoided } \\
\text { deforestation }\end{array}$ & Rest of USA & PEM & $0-92$ & US EPA, 2005 \\
\hline $\begin{array}{l}\text { Avoided } \\
\text { deforestation }\end{array}$ & Pacific NW USA & PEM & $8-16$ & US EPA, 2005 \\
\hline $\begin{array}{l}\text { Avoided } \\
\text { deforestation } \\
\text { (reduced timber } \\
\text { sales) } \\
\end{array}$ & Pacific NW USA & $\begin{array}{l}\text { Econometric } \\
\text { model }\end{array}$ & $\begin{array}{l}43 \text { West region } \\
58 \text { continental US } \\
84 \text { US and Canada }\end{array}$ & $\begin{array}{l}\text { Wear and } \\
\text { Murray, } 2004\end{array}$ \\
\hline $\begin{array}{l}\text { Biofuel production } \\
\text { (short rotation) }\end{array}$ & USA & & 0.2 & US EPA, 2005 \\
\hline
\end{tabular}

